\title{
A Reading Class Design Based on English Discipline Ability
}

\author{
Rong Wang
}

Postgraduate in Yangtze University, China

Received: 14 Jun 2021; Received in revised form: 10 Jul 2021; Accepted: 18 Jul 2021

C2021 The Author(s). Published by TheShillonga. This is an open access article under the CC BY license

(https://creativecommons.org/licenses/by/4.0/)

\begin{abstract}
The paper illustrates how to develop students' English discipline ability based on a detailed reading class design of high middle school in China. With the guidance of key competences, text analysis, teaching objectives and activities design help students improve their English discipline ability so that students can acquire language deeply and apply knowledge into action easily.
\end{abstract}

Keywords - English discipline ability, teaching reading, key competences.

\section{INTRODUCTION}

The publish of English Course Curriculum in China points out that the necessity to develop students' key competences and implement moral education. "Key competences" is a complicate concept, comprising of quality, abilities and many factors. It is students' different behaviors of their different age and learning stage. However, discipline ability is students' cognitive ability on a certain discipline, such as English. Particularly, English is an instrumental and humanistic subject at the same time, which explains the importance of English discipline ability in position of key competences.

However, the current situation is in reading class, teachers focus much attention on form, like structure, grammar and mechanical practice, which are not enough to help students develop English discipline ability. The model of English Discipline Ability proposed by Wang Qiang in China, supports first-line teachers a new way to combine the development of English discipline ability with the reading class design.

\section{THE MODEL OF ENGLISH DISCIPLINE}

\section{ABILITY}

Generally speaking, English discipline ability refers to a kind of steady ability used to deal with English problems, involving observation, interference and other factors. English subject performance ability refers to behaviors or actions that learners take in certain contexts. They apply language knowledge and strategies to communicate and deal with problems(Wang Qiang, 2018). Actually, the author believes that English discipline ability is a tool to externalize students' cognitive level, which benefits teachers to reflect teaching process and improve students learning ability.

The model of English discipline ability involves three dimensions. They are core content dimension, core competence dimension and core activity dimension. The core activity dimension involves listening, speaking, reading and writing; the core content dimension involves life and affection, healthy and safety, nature and environment, science and technology, history and society and literature and art; and the core competence dimension 
involves three layers: learning and understanding, applying and practicing and transferring and creating. It is obvious that core activity dimension is aligned with English skills, which aims to develop English discipline ability through skills training. The core content dimension covers topics and themes in daily life, including language knowledge and cultural knowledge at the same time, which is not only connected with students' real life tightly but cultivate their correct values helpfully. And the core competence dimension starts from students' cognitive levels, choosing different learning activities and helping them learn, understand, internalize and apply knowledge gradually.

Moreover, these three dimensions are positively correlated with each other. English skills improvement helps learners accumulate enough language and cultural knowledge which gives basis for students to face with new contexts and problems. At the same time, the immediate and advanced learners could use English to think and cultivate their own higher order thinking. With the expansion of core content dimension,students are encouraged to acquire and internalize knowledge through various, authentic comprehensive and interesting activities. When the learning content is more difficult, students begin to think independently, form into their own opinions and view this world critically so that they can improve their cognitive level step by step. At last, the development of core competence is a cycle process. The improvement of cognition guides learners know learning methods, reflect learning process and strengthen their confidences when facing with new difficulties.

\section{A READING CLASS DESIGN BASED ON ENGLISH DISCIPLINE ABILITY}

The teaching design is based on a reading text_-From Problems to Solutions selected from Unit1 Cultural Heritage of Book2, PEP Edition.

\section{Text Analysis}

The text is the first reading passage of Reading and Thinking part, belonging to "reading" part of core content dimension. In the whole unit, the passage plays a role of transition because it continues the topic of last listening and reading class_cultural heritage protection and at the same time, introduces the language points of next class.
The main ides of this passage is how the Egyptian government deals with the problem between economic development and cultural heritage protection with the help of other countries and form into "the Aswan Spirit" a last. The passage involves six paragraphs which can be divided into three parts based on chronological order and the process of dealing with the problem. It is about how the government take down cultural relics piece by piece, move temples, build Aswan Dam with the economic and technological help from other countries. From the perspective of core content, it belongs to history and society category, relating to human and society development and cultural heritage protection. There are three clues involved in the text. One of them is obvious - timeline and the others are the process of dealing with problem and how the government is helped by others. The theme of this text not only delivers the logical order of solving problems, that is discovering problems, giving the plan, implementing the plan, recording the result and reflecting the process, but also the international spirit of unity. As for how to develop students' English discipline ability, the focuses should be focused on the teaching activities.

2. Teaching design based on three layers of core competences dimension

With the guidance of key competences, the teaching objectives are designed as following. At the end of the class, students will be able to

- get the main idea of the passage through jigsaw work.(Main idea: Egyptian government solved the problem of building a dam and protecting cultural heritage with the help from the world.).

- analyze and generalize details of the passage (the process of protecting Egypt's cultural relics) based on timeline, and finish the mind-map to better understand the logical sequence of the passage(from problem to solution ) to develop students cognitive strategy.

- realize the importance of cultural relics protection through discussion and try to create another program plan to protect cultural relics by imitating the solving process of the Aswan Dam project.

(1) Activities design of learning and understanding 
layer:

\section{(1)Perception and attention__ introduce the topic}

The teacher shows a 50 yuan RMB and asks students to observe what on the back side is of this paper money. It is Potala Palace, one of famous cultural heritage in China. Then, the teacher presents an interesting picture on screen, which is a combination of Potala Palace. Half of it is on the money, and the other half lies in Tibet Plateau. And the teacher guides students to think about whether two halves of Potala Palace could fit with each other very well. Students find out that no matter size, color, or shape, they could not fit with each other very well. And the teacher presents the topic: Economic development or cultural heritage protection, that's a question! Then, the teacher leads in the topic_Egyptian government face with the same problem naturally.

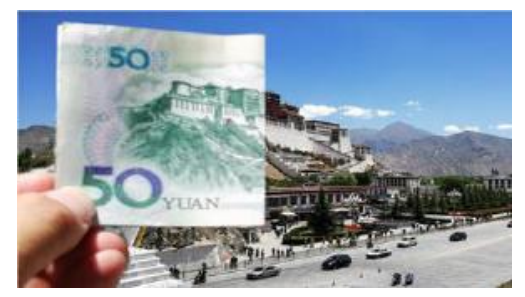

[Justification]

The class begins with the students' familiar money and picture and they are motivated to activate their prior knowledge and think about the relation between money and the Potala Palace. 50 yuan is a symbol of economic development and the Potala Palace is one of cultural heritages. But they could not fit with each other means there is conflict between economic development and cultural heritage protection. Facing with the same problem, the Egyptian government deals with it successfully arouses students' curiosity.

(2) Extraction and generalization-get the main idea

Students are divided into six groups and each group read one paragraph. After reading the certain paragraph, students are expected to extract and generalize the main idea of the paragraph and one of them as leader to share it with others. Each group share main idea of one paragraph so that all of students could get main idea of whole passage. At last, the teacher helps them conclude it and presents a general impression of whole passage.

\section{[Justification]}

On the basis of jigsaw reading, students focus on one paragraph and generalize main idea of it. Taking advantage of information-gap, jigsaw reading not only saves time on the first fast reading, but also supports opportunities for students to express themselves in English. And in the way of dividing a difficult task into pieces would ease the burden for students but set higher requirements for students who share ideas with others because they are expected to help others to understand the passage generally, clearly, correctly and comprehensively.

(2) Activities design of applying and practicing layer

(1) Description and explanation—grasp detailed information

The teacher guides students to focus on numbers which is about year in the passage during the second reading, and asks students to choose subtitles for government's measurements which are matched with time points. Then, the teacher asks students to read text at the third time and answer questions of each time point so that students grasp specific information involved in the text and find out how Egyptian government deal with the problem step by step. For example, the teacher presents the question like "Why did the Egyptian government turn to United State for help?Why did the Egyptian government want to attempt the building of the dam?" Students read the passage and locate the answer and explain it by key words. About time point of 1960, the question like "How were the temples and other cultural sites were saved?", students locate and describe the process and the teacher helps them identify and record the important words of this passage, such as committee, establish, prevent, contributions, documents and so on.

\section{[Justification]}

Students have got main idea of whole passage, then the focus is transferred to detailed information. The matching task aims to help students identify what measurements the government take to deal with problem step by step. The questions of each time point is to add details of measurements so that students can understand the text clearly and set foundation for the following reading activities. No matter matching task or questions, they both require students to use scanning strategies and 
read the text sentence by sentence. At the same time, in the process of describing and explaining, the important vocabularies are presented can avoid teaching them pieces by pieces and without context.

(2) Analysis and Illustration_-explore the theme

The teacher guides students to explore theme of the passage through questions-chains. For example, Q1:A lot of money and time were spent to protect the temples.Do you think it is worthwhile? Why and why not?. These questions aims to prompt students to think about whether it is worth spending too much money to protect cultural heritage and help them set the value of cultural heritage protection. Q2: Why do you think so many countries contribute funds and offer help to the Egyptian project? Q3: And what is "the spirit of the Aswan Dam"? These questions are asked in order to focus students' attention on the essential of Aswan spirit.

[Justification]

Students discuss whether it is worth protecting cultural heritage so that they could think about and face with the conflict directly and perceive the necessity and importance of protection. And the teacher helps them clear the opinion that we need to prevent cultural heritage from damage which is accordance with the theme of this passage. However, the passage not only delivers the value that we need to protect cultural heritage. The Aswan Spirit is also the wealthy that people get from this passage. The question-chain facilitates students to think deeply. And the questions are not confined into grasping facts but activate students' higher order thinking.

(3) Generalization and Integration-extract the internal logic

Students read the text again and try to generalize and name the steps that Egyptian government deals with the problem. The teacher gives an example as scaffold at first. "Water from the dam would likely damage a number of temples and destroy cultural relics that were an important part of Egypt's cultural heritage" can be named as "Discovering Problems". Then, students try to name the following steps or measurements and conclude the logical sequence.

[Justification]
Students understand the theme is the first step of implementation of moral education and the thinking train is also an important part of English teaching. Especially for natural science, the process from discovering problems to solving problems is a highly logical process, which also brings enlightenment for students in life and learning. And the reflecting part involved in Egyptian government is the Aswan spirit, which cultivates students' good thinking habit.

(3) Activities design of transferring and creating layer

(1) Imagination and Creation—deal with new problem

The teacher gives another problem that Mogao Caves is facing with_conflict between the extension of tourism and wall pictures protection. The teacher needs to introduce current situation and reasons of Mogao Caves in details. Students are expected to imitate the Aswan Project to give a plan for Chinese government.

\section{[Justification]}

During the process of grasping detailed information, students have acquired important vocabularies, which gives language scaffold to give a plan. And the Mogao Caves gives students another but similar context in which students could apply what they have learned to deal with authentic problem. Integrating their world knowledge and imagination and creating a protection plan is a good way for students to change paper-knowledge into actions.

(2) Reflection and Conclusion-improve their protection plan

The homework part is that students could search more information about Mogao Caves, like the difficulties in the process of protection and so on. Then, students need to reflect whether their plans could be taken into actions. Then, try to adapt and revise their plans.

\section{[Justification]}

This activity is aligned with the step of reflecting process, strengthening the awareness of reflection. And the thinking quality training and moral education are combined into activities. 


\section{REFLECTION}

1. In the activities of learning and understanding, students do not get enough language input. It results in no strong language basis for students when they move into discussion and writing protection plan.

2. In the activities of applying and practicing, the teacher guides students to generalize and conclude each step of solving problem but they just stop on naming steps and don't go back to the topic of cultural heritage protection.

3. In the activities of transferring and creating, students do not follow the process to solve problems strictly.The logical order aims to help students divide the difficult problems into pieces. But some students just give solutions in their opinions, which could not be taken into actions.

\section{CONCLUSION}

A reading design based on English discipline ability is to integrate the objective of developing English discipline ability into the whole class and activities. It is a continuous and gradual process. Based on students real cognitive and language level, designing activities carefully helps develop students key competences.

\section{REFERENCES}

[1] 贺亚丽, 马欣, 李春芳, 冯娟. 基于英语学科能力要素框 架的高中英语阅读教学课例改进 $[\mathrm{J}]$. 中小学外语教学 (中学篇),2018,41(06):6-11.

[2] 教育部. 普通高中英语课程标准(2020 年版)[M]. 北 京:人民教育出版社, 2018 .

[3] 人民教育出版社. 2019 . 普通高中课程标准实验教科 书·英语 2(必修模块) [T]. 北京: 人民教育出版社.

[4] 王蓄. 基于学生核心素养的英语学科能力研究 [M]. 北京师范大学出版社, 2018.

[5] 王蓄, 胡亚琳. 英语学科能力及其表现研究 [J]. 教育 学报,2017,13(02):61-70.

[6] 王蓄,赵连杰,鲁美芸, 贺亚丽, 王瑜.“中小学生英语学 科能力表现框架” 在英语教学和测评中的应用 $[\mathrm{J}]$. 英 语学习,2018,\{4\}(02):17-26.
[7] 熊苗. 基于英语学科能力要素的高中英语阅读教学 设计的行动研究 [D].海南师范大学, 2019 . 